Hispania Sacra, Legalidad y conflictos, 58 117, enero-junio 2006, 145-170, ISSN: 0018-215-X

\title{
LA JURISDICCIÓN ECLESIÁSTICA DE LA REAL CAPILLA DE MADRID (1753-1931)
}

\author{
POR \\ BEATRIZ COMELla \\ Doctora en Historia, Universidad de Alcalá
}

\section{RESUMEN}

Desde sus orígenes medievales hasta el Concordato de 1753, la Real Capilla de Palacio de Madrid ha sido una peculiar jurisdicción, a la que se pertenecía por el hecho de ser cortesano o trabajar para el rey. Al frente de la Real Capilla estuvo, desde el siglo XVI, el Pro-capellán de Palacio que tenía el título honorífico de Patriarca de las Indias Occidentales. Desde mitad del siglo XVIII, para evitar pleitos con otras jurisdicciones eclesiásticas, los Papas Benedicto XIV y Pío VI señalaron unos límites territoriales a la Real Capilla que pasó a ser, de hecho, una prelatura vere nullius, integrada por la Parroquia Ministerial de Palacio, la Parroquia de El Pardo y la Parroquia de Aranjuez, aunque, no llegó a ser erigida como tal prelatura. A principios del siglo XIX hubo un intento fallido de convertir la Parroquia palatina en catedral, no obstante, el Concordato de 1851 mantuvo la privilegiada jurisdicción de la Real Capilla que perduró hasta el 1 de abril de 1933.

PALABRAS CLAVE: real capilla, jurisdicción, concordato, Pro-capellán de Palacio, Patriarca de las Indias Occidentales.

\section{ABSTRACT}

From its medieval origins up to the Concordat of 1753, the Chapel in the Royal Palace, the Royal Chapel, was holding a particular jurisdiction and people belonged to it for the fact of being a courtier or work at the king's service. Since the XVI century the Royal Chapel has been headed by the Pro-Chaplain of the Palace who was bearing the honorific title of Patriarch of the West Indies. By the middle of XVIII century, in order to avoid legal disputes with other ecclesiastical jursidictions, the Popes Benedict XIV and Pius VI, decided to set territorial limits to the Royal Chapel and, in fact, it became a vere nullius Prelature, - even if it was never erected as such-, constituted by the Ministerial Parish of the Royal 
Palace, The Parish of El Pardo, and The Parish of Aranjuez. At the beginning of the XIX century there was an attempt to convert the Royal Parish into cathedral, but it failed. Nevertheless, the Concordat of 1851 maintained the privileged jurisdiction to the Royal Chapel, and so it lasted up to the first of April 1933.

KEY WORDS: Royal Chapel, jurisdiction, Concordat, Palace Pro-Chaplain, Patriarch of the West Indies.

La historiografía sobre la jurisdicción eclesiástica de la Real Capilla de Madrid es relativamente escasa, aunque las fuentes documentales sobre la misma son amplias, pero han sido poco estudiadas hasta ahora ${ }^{1}$. Durante los siglos XIX y XX esta peculiar jurisdicción fue objeto preferente para estudiosos del derecho canónico y civil; pocos historiadores se han interesado por ella ${ }^{2}$. Prácticamente todos los que le han prestado atención han fundamentado sus investigaciones en la normativa legal de la Real Capilla, es decir, en su funcionamiento teórico. Faltaba, por tanto, una puesta al día de carácter histórico-jurídico basada en documentos inéditos sobre la articulación práctica de la Real Capilla madrileña ${ }^{3}$.

\section{ORÍGENES DE LA JURISDICCIÓN ECLESIÁSTICA DE LA REAL CAPILlA}

A mitad del siglo XVIII, concretamente, tras el Concordato entre la Santa Sede y el Reino de España de 27 de junio de 1753, se erigió la Real Capilla de

\footnotetext{
1 La principal fuente para su estudio es la amplia Sección de Real Capilla del Archivo General de Palacio (AGP) de Madrid, perteneciente a Patrimonio Nacional.

${ }^{2}$ Entre los juristas, puede destacarse a: L. FRíAs, «El Patriarcado de las Indias Occidentales. Nuevas investigaciones históricas», Revista de Estudios eclesiásticos, 1 (1922); F. FuIz GARCíA, «Patriarcado de las Indias y Vicariato General Castrense», en Revista Española de Derecho Canónico, 23 (1967); J. Postíus y SALA, El derecho canónico aplicado a España, Ed. Corazón de María, Madrid, 1926, y J. B. FERreres, Instituciones canónicas, . $^{\text {a }}$ ed., Ed. Subirana, Barcelona, 1926; A. VianA, Organización del gobierno de la Iglesia, EUNSA, 2. ${ }^{a}$ ed., Pamplona, 1997, y J. Miras, Praelatus: de Trento a la primera codificación, EUNSA, Pamplona, 1998; A. LiNAGE CONDE, Patriarcat des Indes Occidentales, en R. AuberT (dir.), Dictionnarire d'Histoire et de Geographie eclesiastiques, vol. XXV, Ed. Letouzey et Ané, París, 2001. Se citará DHGE. Vid. también, del mismo autor, «La Real Capilla de la Corte de Madrid», Revista Abadía, II Jornadas de Historia (Abadía de Alcalá la Real). Diputación Provincial de Jaén (1998). Se citará ABADÍA.

Entre los historiadores: V. DE LA FuENTE, Historia eclesiástica de España, tomos V y VI, Compañía de Impresores y Libreros del Reino, Madrid, 1873; C. FERNÁNDEZ Duro, «Noticias acerca del origen y de la sucesión del Patriarcado de las Indias Occidentales», Boletín de la Real Academia de Historia, 7 (1885); E. BAZÁn Ocón, La jurisdicción palatina en España, Tesis de Doctorado, Pamplona, 1986; VV.AA., Diccionario de Historia eclesiástica de España, 4 vols., CSIC, Madrid, 1975. Se citará en adelante DHEE, M. V. QUERO, «Capilla Real», en DHEE, vol. I, pp. 338-339.

3 Esta cuestión ha sido estudiada por la autora de este artículo en su tesis doctoral: Vid. B. ComELla GutiérReZ, La jurisdicción eclesiástica palatina en los Patronatos reales del Buen Suceso y de Santa Isabel de Madrid (1753-1931), Fundación Universitaria Española, Madrid, 2004.
}

Hispania Sacra, Legalidad y conflictos, 58

117, enero-junio 2006, 145-170, ISSN: 0018-215-X 
Madrid en parroquia de la que dependían la familia real, los cortesanos y la servidumbre de palacio.

Por dicho acuerdo bilateral, Benedicto XIV confirmó mediante breve dirigido a Fernando VI los privilegios que desde la Edad Media poseía la Real Capilla y delimitó un territorio palatino exento de la archidiócesis de Toledo, integrado por los palacios reales y los Reales Sitios ${ }^{4}$. Dicho territorio contaba, a mitad del siglo XVIII, con 1992 habitantes inscritos en un registro denominado Libro Rool ${ }^{5}$. Esta peculiar jurisdicción palatina funcionó hasta el advenimiento de la II República.

¿Cuáles son los precedentes históricos de esta jurisdicción especial? Para argumentar la exención respecto a la sede primada, un tratadista del siglo XVIII se remonta a una fecha anterior a la conversión de Recaredo y los visigodos en el III Concilio de Toledo (año 589). El precedente de la jurisdicción palatina, apoyándose en el testimonio de las Partidas de Alfonso X el Sabio, debía situarse en una fecha previa. El origen de la Real Capilla castellana dataría del reinado del suevo Teodomiro que, persuadido por San Martín de Dumio, abandonó el arrianismo para abrazar la fe católica, según consta en los documentos del Concilio de Lugo (año 567), en el que los padres sinodales constituyeron la diócesis de Dumio cuyo Obispo sería capellán real, con ciertas particularidades: «aunque a todos los Obispos, escribe el Patriarca Cardenal Mendoza, desde los principios de la Iglesia, se les señaló diócesis o territorio fijo con designación de límites, al Capellán Mayor, obispo de Palacio, no se le ciñó su oficio a ciertos términos y confines como a los demás, permitiéndole ejercer su cuidado pastoral y jurisdicción dondequiera que estuviese el Rey, su familia y su Corte» ${ }^{6}$. Tras la conquista musulmana, sigue exponiendo, la sede dumiense se trasladó a Mondoñedo y, para agradecer al apóstol Santiago su ayuda en la reconquista, el Capellán Mayor del Rey pasó a ser el Arzobispo de la sede compostelana; fue Alfonso VII de Castilla quien consiguió del Papa Inocencio II en 1140 el nombramiento como Capellán Mayor real de Diego Gelmírez, Arzobispo de Santiago de Compostela ${ }^{7}$. La Santa Sede tam-

\footnotetext{
4 Vid. Real CAPILla, Bulas y Breves Pontificios relativos a la jurisdicción privilegiada de la Real Capilla, Imprenta Real Capilla, Madrid, 1878. Se citará BBP.

Madrid dependió de la Archidiócesis de Toledo hasta 1885 Se creó por la Bula de León XIII Romani Pontífices Praedecessores. Vid. F. DÍAZ DE CERIO, Índice-Catálogo de Fondo de la Nunciatura en Madrid en el Archivo Vaticano 1794-1879, tomo III, Universidad Gregoriana, Roma, 1993.

5 El «Libro Rool de 1756» está publicado en $B B P$, pp. 116-322.

6 Vid. Memorial del Cardenal Mendoza, Patriarca de las Indias Occidentales al Cardenal Arzobispo de Toledo, Antonio Fernández de Córdoba (17-8-1756), AGP Real Capilla C. ${ }^{\text {a }}$ 64/13. Álvaro Eugenio Mendoza Caamaño y Sotomayor fue Patriarca entre los años 1734 y 1761; antiguo servidor de la Real Capilla, había sido sumiller de cortina desde 1698, beneficiario de Antequera, arcediano de Toledo, Arzobispo titular de Farsalia y cardenal (1750).

7 Cfr. AGP RC C. ${ }^{\text {a }} 72 / 9$.
} 
bién otorgó diversos privilegios a la Real Capilla de la Corona de Aragón durante la Edad Media ${ }^{8}$.

El Papa Gregorio IX (1227-1241) permitió en 1234 que, por privilegio pontificio, se concediera a las capillas reales la exención de la jurisdicción ordinaria y se considerara al Capellán Mayor dotado de potestad quasi episcopal, de carácter personal, es decir, vinculado a las personas de la familia real y los cortesanos que seguían al Rey, ya que por entonces las Cortes reales de Castilla y Aragón no tenían sede fija9.

Ya antes de que la Casa de Austria fijara la Corte en Madrid de modo definitivo a principios del siglo XVII, se produjeron algunos cambios en la Real Capilla puesto que Carlos V unificó las capillas reales de Castilla y Aragón, tomando las pautas de funcionamiento y protocolo de la capilla real borgoñona, cuya tradición permaneció también bajo la dinastía borbónica ${ }^{10}$. Sin embargo, la jurisdicción palatina no adquirió unos límites territoriales precisos, como se ha señalado, hasta 1753 y mantuvo su fundamento personal: no afectaba a territorios sino a los cortesanos y a los que acompañaran al rey en sus viajes o jornadas ${ }^{11}$.

\section{El Patriarca de las Indias Occidentales, Pro-Capellán mayor de Palacio Y VICARIO GENERAL CASTRENSE}

Históricamente, la jurisdicción palatina está unida al cargo de Pro-Capellán Mayor de Palacio y al título honorífico de Patriarca de las Indias Occidentales. Dos hechos concretos están relacionados con el origen de esta dignidad eclesiástica.

En primer lugar, la obligación de residencia para los obispos dictada por el Concilio de Trento; el decreto propició que Felipe II solicitara a Pío V la crea-

\footnotetext{
8 Por ejemplo, el de considerar capillas reales, entre otras, en la Corona de Aragón: Alquézar, Aljafería de Zaragoza, Santa Águeda de Barcelona, Almudaina en Mallorca y Perpiñán. Cfr. DHEE, «Capilla Real», vol. I, pp. 338-339.

9 Cfr. Gregorio IX, Decretales (año 1234), libro V, cap. 16, tít. 43, Roma, 1720 versión de J. M. Mans Puigarnau, Ed. Casa Provincial de la Caridad, Barcelona, 1939.

Sobre la Real Capilla en la etapa de los Trastámara, Vid. L. SuÁrez Fernández, Nobleza y Monarquía: puntos de vista sobre la historia política castellana del siglo XV, Departamento de Historia Medieval, Universidad de Valladolid, 1975.

10 Vid. M. Jorreto Paniagua y P. Soler Mora, Guía Palaciana, t. III, ed. Vda. Hernando y C. a de Sucesores de Rivadeneyra, Madrid, 1896-1902, y DHEE, «Capilla Real», vol. I, pp. 338-339.

11 Carlos V viajó por media Europa, Felipe II acudía con frecuencia a El Pardo y El Escorial, Felipe III trasladó temporalmente la Corte a Valladolid, Felipe IV pasó largas temporadas en el Buen Retiro. El calendario habitual de la Corte en el siglo XVIII era: invierno en El Pardo, primavera en Aranjuez, verano en La Granja y otoño en El Escorial. En el Palacio real de Madrid, la Corte permanecía anualmente pocas semanas. Cfr. B. PINTO CRESPo y S. MADRAZo, Atlas histórico de la ciudad siglos IX-XIX, Fundación Caja Madrid-Lunwerg, Madrid, 1995, p. 288, se citará ATLAS.
}

Hispania Sacra, Legalidad y conflictos, 58

117, enero-junio 2006, 145-170, ISSN: 0018-215-X 
ción del cargo de Pro-Capellán para que ejerciera en la Corte la jurisdicción palatina que correspondía desde el siglo XII al Capellán Mayor del rey, Arzobispo de Santiago de Compostela. En ese sentido, afirma León Pinelo en sus Anales de Madrid: «aunque el Arzobispo de Santiago por privilegios antiguos de los Reyes es Capellán Mayor de la Real Capilla, como es forzoso que falte a la residencia, este año (1569) sacó el Rey Don Felipe Bula de Pío Quinto para que en ausencia del Arzobispo pueda nombrar quien sirva el cargo de Capellán Mayor» ${ }^{12}$. El ejercicio de la jurisdicción palatina por el Pro-Capellán como vicario del Capellán Mayor se verificó en 1610, bajo el reinado de Felipe III.

En segundo lugar, la atribución del título honorífico de Patriarca de las Indias Occidentales a dicho Pro-Capellán, gracia solicitada previamente por Fernando el Católico a la Sede Apostólica con una finalidad distinta.

El título de Patriarca de las Indias Occidentales se utilizó entre 1524 y 1963, es decir, durante 439 años y estuvo ordinariamente unido a las jurisdicciones palatina y castrense. A lo largo de su larga historia, el Patriarcado sufrió muchas vicisitudes, que se resumen en las siguientes líneas.

Inicialmente este prelado debía haber sido una suerte de primado eclesiástico para América; al menos esa era la intención de Fernando el Católico al solicitar el título de Patriarca de las Indias del Mar Océano, como se le denominó entonces ${ }^{13}$. El rey pidió en 1513 a León X, a través de su embajador en Roma, Jerónimo de Vich, dicho título para su capellán personal, Juan Rodríguez de Fonseca, Obispo de Rossano (Nápoles), y con él, el gobierno espiritual de las Indias $^{14}$.

La respuesta de Roma fue negativa. No obstante, Carlos V, haciendo uso de las prerrogativas del patronato regio otorgadas por Adriano VI, (Adriano de Utrecht había sido consejero del emperador) lo solicitó de nuevo, alegando la lejanía de América y la necesidad de una jurisdicción especial para remediar abusos en las tierras descubiertas. Parece que dicho Patriarcado fue otorgado por primera vez por Clemente VII a Antonio de Rojas, arzobispo de Granada, Presidente del Consejo de Castilla y capellán de Carlos V en 1524, aunque no se conoce la Bula de concesión ${ }^{15}$.

Dado que el Patriarcado de las Indias había sido otorgado pero con carácter meramente honorífico, Felipe II solicitó a Pío IV, a través de su embajador el Conde de Tendilla, el nombramiento de dos prelados especiales para Perú y

12 Cfr. L. Pinelo, Anales de Madrid desde el año 447 al 1658, Instituto de Estudios Madrileños, Madrid, 1971, p. 94., y J. PAREdes (dir.), M. BARrio, D. RAMOS-Lisson y L. SuÁREZ, Diccionario de los Papas y Concilios, Ariel Referencia, Madrid, 1998, pp. 631-634.

13 Este título se utilizó hasta 1606. Cfr. DHGE, pp. 1041-1042.

14 Cfr. J. Ferreres, o. c., p. 222.

15 Cfr. Q. AldEA, «Patriarcado de las Indias», DHEE, vol. IV, pp. 1887. 
México, con atribuciones en materia de causas matrimoniales y beneficiales, a fin de paliar las dificultades del gobierno eclesiástico de América. En 1560, el Papa Pío IV concedió que los arzobispos de las citadas diócesis pudieran actuar como jueces de primera instancia en determinados $\operatorname{casos}^{16}$. El Rey prudente renovó sus peticiones a Roma en 1568 y 1572 pero la respuesta fue negativa ${ }^{17}$.

A finales del siglo XVI, las aspiraciones de los Austrias sobre un efectivo Patriarcado en las Indias Occidentales parecían haber fracasado; visto que Roma no tenía intención de hacer concesiones para América, los monarcas españoles trataron de conseguir otras atribuciones para el título patriarcal, que se concretaron en unir dicho honor, como se ha explicado, al cargo de Pro-Capellán de Palacio, hecho que se verificó en $1610^{18}$. Como tal, del Patriarca dependieron jurisdiccionalmente la familia real con sus servidores, los miembros de la Real Capilla independientemente del lugar donde estuvieran y los que vivieran o trabajaran en los Palacios reales, en los Reales Sitios (Buen Retiro, El Pardo, El Escorial, La Granja, Aranjuez, La Florida-Moncloa) y en los Patronatos de la Corona ${ }^{19}$.

Posteriormente, a partir de 1644, al Patriarca se le otorgó también la jurisdicción castrense; por diversas circunstancias, quedó suspensa entre 1716-36, pero el 4 de febrero de 1736, el Papa Clemente XII, mediante el Breve Quoniam in exercitibus, renovó el Vicariato Castrense para tiempo de guerra y otorgaba facultades ampliadas a época de paz sobre los militares y sus familias. Este acuerdo fue actualizado cada siete años desde Carlos III, fue nuevamente abolido en 1750-1762 y 1769-1772 hasta su supresión en $1933^{20}$.

El Patriarca ostentó también, desde el Reinado de Felipe III, el cargo de Limosnero Mayor, heredado, como otras tradiciones, de la Real Capilla de Borgo-

\footnotetext{
16 Cfr. Ibidem.

17 Felipe II pretendía que el Patriarca formara parte del Consejo de Indias y que de él dependieran los primados de México y Lima. Cfr. DHGE, p. 1041.

18 Por expresa voluntad del Papa Adriano VI (1522-1523), el Patriarca de las Indias tenía prohibido relacionarse con las posesiones españolas de América, sin embargo, desde el pontificado de Inocencio X (1644-1655), al recibir la jurisdicción castrense estuvieron bajo el régimen o gobierno eclesiástico del Patriarca los militares españoles destacados o establecidos en los territorios de Ultramar.

19 En Madrid capital: Basílica de Atocha, Monasterio y Colegio de Santa Isabel, Colegio de Loreto, Iglesias y Hospitales del Buen Suceso y de Montserrat. Los Monasterios de las Descalzas Reales (fundado por la Princesa Juana de Portugal, hermana de Felipe II en 1559) y de la Encarnación (fundado por Margarita de Austria, esposa de Felipe III, en 1611) también son Patronatos reales, pero dependieron respectivamente del Arzobispo de Santiago de Compostela y del Ordinario diocesano. Sobre la evolución del Patronato regio y los Patronatos reales, Vid. L. LóPEz Rodó, El Patrimonio real, CSIC, Madrid, 1954, y J. L. SANCHO, La Arquitectura de los Sitios Reales: catálogo histórico de los Palacios, jardines y Patronatos reales del Patrimonio Nacional, Patrimonio Nacional, Madrid, 1996. Aunque la última es una obra de carácter artístico y técnico, resume de modo actualizado el ejercicio del Patronato sobre instituciones religiosas y benéficas.

20 Vid. DHEE, «Vicariato Castrense», vol. IV pp. 2743-2746.
}

Hispania Sacra, Legalidad y conflictos, 58

117, enero-junio 2006, 145-170, ISSN: 0018-215-X 
$\tilde{n}^{21}$. Además fue Miembro nato de la Junta de Obras y Bosques, organismo creado por Felipe V, independiente de cualquier Consejo real, para administrar y gobernar los bienes de la Corona, hasta la primera década del siglo XIX, en que dejó de funcionar. Durante dicha centuria estuvo también vinculado a la Junta de Beneficencia, por su relación con Colegios de fundación real y pasó a ser, como otros prelados españoles, senador del Reino ${ }^{22}$.

\section{EVOLUCIÓN DE LA JURISICCIÓN PALATINA BAJO LA CASA DE BORBÓN}

Como se ha indicado, si bajo los Austrias españoles se obtuvo de Roma la vinculación de las jurisdicciones palatina y castrense al título de Patriarca de las Indias Occidentales, en la misma línea regalista, la Casa de Borbón se empleó a fondo para fortalecer este cargo con más privilegios. En 1716, Clemente XI concedió a Felipe V que el Pro-Capellán fuera «rector para corregir, visitar y ejercer omnímoda jurisdicción ordinaria, como acostumbran los Arzobispos, Obispos y demás Ordinarios locales (...) en virtud de dicha autoridad apostólica, con omnímoda jurisdicción en cualidad de Juez, así de la Corte y Palacio, como de la Capilla (...) así como de los que estuvieren en sus casas o Palacios de campo» ${ }^{23}$. No obstante, el cenit de la jurisdicción palatina se alcanzó en la segunda mitad del siglo XVIII, tras el Concordato de 1753 y un Breve papal de 1777 .

Como es sabido, durante el reinado de Fernando VI, España firmó un Concordato con la Santa $\operatorname{Sede}^{24}$ y, a petición del Rey, Benedicto XIV aprobó un Breve, fechado el 27 de junio de 1753, por el que se erigió la Real Capilla de Palacio en parroquia, a la que pertenecían las personas de la jurisdicción palatina, y cuyo pastor espiritual, dada la ausencia habitual del capellán Mayor, era el Pro-Capellán de Palacio y Patriarca de las Indias Occidentales. Su jurisdicción era omnímoda, privativa, episcopal o quasi episcopal vere nullius, es decir, equiparable a la de un obispo.

Los capítulos 6 a 34 de la Bula se dedican a enumerar los privilegios de la Real Capilla, muchos de ellos, concedidos por los predecesores de Benedicto $\mathrm{XIV}^{25}$. Pueden dividirse según su sujeto en:

21 Cfr. DHGE, p. 1041.

22 Cfr. AGP Expediente personal PER 231/8 y ATLAS, p. 246.

23 Cfr. $B B P$, p. 98 En este mismo documento concede a los Capellanes de honor de la Real Capilla seguir percibiendo las prebendas de sus diócesis de origen.

24 Vid. R. S. DE LAMADRID, El Concordato español de 1753 según los documentos originales de su negociación, Cromo-Tipografía, Jerez de la Frontera, 1937.

25 Vid. BBP, pp. 261-279. 
Facultades del Rey:

a) Mandar celebrar misa una hora antes del amanecer y otra después del mediodía.

b) Usar altar portátil en viajes y en la propia habitación.

c) Solicitar indulgencias semejantes a las que se pueden lucrar en Roma.

d) Obligar al Pro-Capellán electo a renunciar a otros oficios para dedicarse exclusivamente a la atención de la jurisdicción palatina.

Facultades del Capellán y Pro-Capellán:

a) Exención de la jurisdicción ordinaria.

b) Conocer y terminar causas judiciales de sus súbditos.

c) Dispensar de las penas eclesiásticas como cualquier Obispo.

d) Elegir confesores, examinarles y darles licencias.

e) Conceder licencias para la administración de los sacramentos.

f) Celebrar misas de pontifical; celebrar en cualquier iglesia a la que acuda el Rey, aunque sea Catedral.

g) Absolver censuras y dispensar en casos de irregularidad.

h) Reconocer testamentos, visitar obras y lugares píos.

i) Publicar y fijar edictos.

j) Ordenar de tonsura y menores y dar cartas dimisorias para recomendar la ordenación sacerdotal a los Obispos competentes.

k) Subdelegar funciones cuando no pueda cumplirlas.

1) Asistir a matrimonios de súbditos o no súbditos, si está presente el Rey.

m) Enterrar muertos de la Familia real y celebrar misa si hay entredicho.

n) Conceder indulgencias a quienes asistan a actos litúrgicos con su Majestad.

o) Ejercer cura de almas entre súbditos naturales y extranjeros.

p) Dispensa de la abstinencia en cuaresma.

Facultades de los demás capellanes, cantores y escolares de la Real Capilla:

a) Recibir las sagradas órdenes.

b) Rezar las Horas como en la Curia Romana.

c) Celebrar según el rito de la Iglesia toledana. 
d) Percibir rentas de cualquier oficio eclesiástico aunque no estén presentes donde se emanan; se permite a doce clérigos de la Real Capilla que sigan percibiendo las rentas y beneficios de su diócesis de origen, eximiéndoles del deber de residencia.

e) Enterrarse en cualquier iglesia.

f) Trabajar en domingo o festivo.

g) Colaborar en los informes de limpieza de sangre.

Privilegios de la Real Capilla:

a) Altar de ánima: indulgencia plenaria cada vez que se celebre en un altar determinado.

b) Indulgencias por la visita a la Capilla Real.

c) Suspensión del entredicho, mientras en ella esté el Rey.

d) Reserva del Santísimo y celebración de la Octava del Corpus.

e) Indulgencia plenaria el día del cumpleaños del Rey a quienes visiten la Real Capilla.

f) Ganar las indulgencias propias de la Real Capilla en cualquier otra iglesia donde se hallare la Corte ${ }^{26}$.

\section{El Breve de Pío VI a CARlos III de 1777}

La exención jurisdiccional obtenida en 1753 produjo una lógica reacción contraria por parte de los Arzobispos de Toledo (entonces Ordinarios territoriales de Madrid) y algunos superiores de órdenes regulares; para solventar los problemas de carácter jurídico, Carlos III solicitó y obtuvo de Pío VI un nuevo Breve, fechado el 4 de abril de 1777, señalando con mayor precisión los límites geográficos de la jurisdicción palatina en y fuera de Madrid.

Se conserva el texto de la Real Cédula del Carlos III, fechada el 31 de mayo de 1777, que manda cumplir el contenido del Breve papal ${ }^{27}$. El Rey reconoce que para solventar los problemas de jurisdicción con la Archidiócesis de Toledo, el Consejo de Órdenes y el Prior del Monasterio de El Escorial, determinó crear una junta de cinco expertos que presentara un estudio pormenorizado a la Santa Sede. Carlos III lo explicó con estas palabras: «habiéndose originado y

\footnotetext{
${ }^{26}$ El hecho de que los feligreses de la Real Capilla puedan lucrar estas indulgencias donde se halle la Corte, indica claramente que se hallan bajo una jurisdicción de fundamento personal.

27 Vid. BBP, pp. 322-324.
} 
suscitado muchas y graves disputas y controversias entre el Cardenal Córdoba, Arzobispo que fue de Toledo y algunos párrocos y superiores de órdenes regulares, los quales alegaban que con la erección de la nueva Iglesia Parroquial quedaban perturbados y ofendidos sus dominios, no habiendo sido ésta la mente de la Santidad de Benedicto Decimocuarto, ni la del Señor Rey Don Fernando, mi muy caro y muy amado hermano, se lo representaron exponiendo sus razones y los derechos que cada uno conceptuaba le competían. Para proceder con la madurez que era correspondiente a un asunto de tanta gravedad, se nombró una junta compuesta de cinco sujetos dotados de doctrina y probidad para examinarlo» ${ }^{28}$.

El Breve de Pío VI trató de solventar los problemas jurisdiccionales. En primer lugar, se expone lo realizado por su predecesor Benedicto XIV: se señaló un territorio y unos feligreses de la real Parroquia de Palacio (el texto original latino dice: declaratio pro rege católico quoad loca et personas comprehensas in territorio parrochiali eius regiae capellae), «para que no se suscitasen pleitos ni controversias sobre la administración de los sacramentos y los demás derechos parroquiales entre el Capellán Mayor de la Real Capilla y los curas párrocos o Rectores de las otras iglesias parroquiales, ni se confundiesen la jurisdicción que corresponde a cada uno de ellos» ${ }^{29}$.

Dado que se habían suscitado pleitos y diferencias, sobre todo entre el Cardenal Arzobispo Fernández de Córdoba y el Cardenal Patriarca Córdoba y Espínola, a fin de evitar nuevos problemas, se volvieron a señalar con todo detalle los límites del territorio palatino. Según el Breve de 1777, se consideraba territorio de jurisdicción palatina:

- Palacio Real: área limitada por la Cuesta de San Vicente, Monasterio de la Encarnación, Convento de San Gil ${ }^{30}$. Plaza de la Armería y Puerta de la Vega.

- Los Conventos, Casas y Colegios pertenecientes con anterioridad a la jurisdicción palatina.

- Reales Sitios de la Casa de Campo y del Buen Retiro (incluyendo la Iglesia y Monasterio de los Jerónimos).

- Reales Sitios de El Pardo, La Zarzuela y Viñuelas exceptuando el Convento de Capuchinos (hasta entonces incluido). Una de las novedades del Breve es que se constituyó una Parroquia palatina en el Palacio de El Pardo ${ }^{31}$.

\footnotetext{
${ }^{28}$ Se refiere a Luis Antonio Fernández de Córdoba, Arzobispo de Toledo entre 1755 y 1771. Cfr. AGP Reinados Carlos III, L. 237.

29 AGP AP RAS Reales Alcázares de Sevilla C. ${ }^{\text {a }}$ 159/22 fol. 3. Se citará en adelante AGP RAS indicando el folio correspondiente.

30 No existe en la actualidad, estaba en la confluencia de las actuales calles Bailén y Requena.

31 AGP RAS fol. 15 y 17.
} 
- Real Sitio de El Escorial: el Palacio y la Iglesia se considerarían de jurisdicción real sólo cuando estuviera el Rey; el Monasterio y Colegio estarían siempre bajo el gobierno y jurisdicción del Prior de los Jerónimos.

- Real Sitio de La Granja de San Ildefonso: Palacio y tribunas reales de la Iglesia; el resto pertenecería al Abad de la Colegiata.

- Real Sitio de Aranjuez: todo el Real Sitio excepto el Convento franciscano de San Pascual. Como en el caso de El Pardo, Aranjuez pasó a constituirse en Parroquia o distrito parroquial propio desde el Breve de $1777^{32}$.

La jurisdicción palatina, por tanto, tuvo desde 1777 tres parroquias: la Ministerial de Palacio, El Pardo y Aranjuez.

Respecto a los viajes del Rey, indica el Papa que tanto el monarca como quienes le acompañen, además de sus criados, quedan bajo la jurisdicción palatina, de la que excluye a quienes sin acompañar al Rey realicen el mismo trayecto. Por lo que respecta a la antigua prerrogativa del Capellán o Pro-Capellán de poder celebrar en cualquier Catedral de España, en presencia del Rey durante sus visitas, Pío VI la anula afirmando que los respectivos Ordinarios estarán agradecidos de recibir a su Majestad en sus respectivas sedes ${ }^{33}$.

En cuanto a los diezmos, el Papa ordena que como la Parroquia palatina está «superabundantemente dotada, por real liberalidad», se donen a la Parroquia a la que se entregaban antes del Breve (a la más cercana del domicilio) ${ }^{34}$; sobre los entierros de feligreses que no sean de la Familia real, se indica que deberán acudir a la más cercana del lugar del fallecimiento ${ }^{35}$.

Pero todavía el Breve ofrece una novedad más que trajo consigo muchas consecuencias: Pío VI no considera feligreses palatinos a los criados de Palacio que vivan fuera del territorio marcado y, en cambio, sí lo son los que vivan en ese territorio señalado, aunque no sean servidores de Palacio, es decir, desde 1777 primó la territorialidad.

Dice el Breve de 1777 textualmente refiriéndose a los feligreses de la jurisdicción palatina: «sean sus feligreses todos los que vivieren en sus territorios y edificios que van aquí antecedentemente designados, de modo que los criados del Rey que vivan fuera de ellos estarán sujetos a las Parroquias de sus respecti-

\footnotetext{
32 Cfr. AGP RAS fol. 17: «Igualmente ha de estar sujeto a la jurisdicción del sobredicho Capellán o Procapellán Mayor el Palacio de Aranjuez, cuyo distrito parroquial quedará enmarcado dentro de los términos siguientes (...)».

33 Cfr. AGP RAS fol. 23.

34 Los diezmos y primicias fueron percibidos por las Parroquias hasta su abolición por Real Decreto de 19-7-1837. Cfr. M. Teruel GREgorio DE TEJADA, Vocabulario básico de Historia de la Iglesia, Ed. Crítica, Barcelona, 1993, p. 143.

35 Cfr. AGP RAS fol. 25.
} 
vos domicilios; y al contrario, los que vivieren en los territorios y edificios que van demarcados, aunque no sean criados del Rey, sean en todo y por todos feligreses del Capellán o Pro-Capellán» ${ }^{36}$.

De este modo, las personas que vivieran o trabajaran en los citados lugares eran consideradas feligreses palatinos ya que se primó desde entonces el criterio de territorialidad sobre el de personalidad.

Los Breves de 1753 y 1777 supusieron, en definitiva, un importante cambio en la jurisdicción palatina que se remonta a la Edad Media. Desde el siglo XII, los capellanes reales fueron acumulando los privilegios pontificios que les posibilitaron el ejercicio de una auténtica jurisdicción personal, avalada por la necesidad de atender pastoralmente a una Corte itinerante. El hecho de que ésta se estableciera definitivamente en Madrid a principios del siglo XVII y las disputas con el arzobispado de Toledo y otras jurisdicciones se tradujo en una progresiva conversión a una jurisdicción palatina de carácter mixto: personal y territorial, dando prioridad al segundo aspecto, si bien nunca se perdió el fundamento personal de la jurisdicción, puesto que la jurisdicción afectaba fundamentalmente a los cortesanos.

Para completar una visión sobre el asentamiento de la jurisdicción palatina durante la edad contemporánea, es necesario aludir al intento de erección de una Catedral en Madrid dependiente de la Real Capilla y al Concordato de 1851.

El primer proyecto había sido acariciado desde varios siglos atrás por la monarquía española: no era la única institución en considerar que la antiquísima Parroquia de la Almudena debía ser elevada al rango catedralicio. Carlos V realizó uno de los primeros intentos en 1518; consiguió la Bula de erección de León X pero no se hizo realidad por la oposición del Arzobispo de Toledo, Guillermo de Croy; Felipe III lo intentó nuevamente, sin éxito, por la resistencia del Cardenal Arzobispo de Toledo, Sandoval y Rojas. Felipe IV, en cumplimiento del testamento de su esposa Isabel de Borbón, mandó realizar un proyecto y determinó la ubicación de la futura Catedral (el lugar coincidía con el actual), pero no siguió adelante. Por otra parte, la primitiva capilla de San Isidro construida en 1622 con motivo de su canonización, fue agrandada en 1788, fecha de su transformación en Colegiata ${ }^{37}$.

Cuando en 1798 Carlos IV y el Patriarca de las Indias Occidentales, Cardenal Sentmenat, retomaron la idea, posiblemente no pensaran en construir un nuevo templo o trasladar la antigua Parroquia de la Almudena, sino en conseguir la aprobación romana para instalarla en San Francisco el Grande, iglesia

\footnotetext{
36 Cfr. AGP RAS fol. 24.

37 Cfr. ATLAS, p. 296.
}

Hispania Sacra, Legalidad y conflictos, 58

117, enero-junio 2006, 145-170, ISSN: 0018-215-X 
terminada por Sabatini en 1784. Sin citar explícitamente esta templo, un testimonio cualificado de la época afirma: corresponde a «Madrid una Iglesia, que a lo menos igualase a la del Escorial en grandeza, y propiedad, donde se juntasen cómodamente el clero secular y regular, y pudiesen concurrir todos sus Consejos, y Tribunales para procesiones públicas, rogativas, hacimientos de gracias, y otras funciones pertenecientes a la Religión» ${ }^{38}$.

El Patriarca realizó los trámites oportunos en la Nunciatura y se obtuvo el pase de la Cámara de Castilla, gestionado por el Ministro Mariano Luis de Urquijo $^{39}$. Sin embargo, por carta del teniente general de Patriarca, fechada el 25 de mayo de 1799, se sabe que el Cardenal Arzobispo de Toledo, Francisco Antonio de Lorenzana, frenó el proyecto ${ }^{40}$. El Primado de España había ordenado realizar, entre los años 1792-1795, a su Vicario en Madrid un informe sobre la redistribución parroquial en la Villa y Corte, aprobado por la Real Orden del 12 de diciembre de $1805^{41}$. Además, la situación era tensa en 1799, ya que el Reino de España había roto las relaciones con la Santa Sede, debido a que el Ministro Mariano Luis de Urquijo se negó a acudir a la Curia Romana para confirmar los nombramientos episcopales, durante la cautividad del Papa Pío VI. Quizá este hecho pudo también frenar el proyecto de Catedral en Madrid ${ }^{42}$. Pasaría mucho tiempo, hasta la firma del Concordato de 1851, que preveía la creación de la Diócesis de Madrid, para que la idea tomara cuerpo nuevamente ${ }^{43}$.

\section{LA JURISDICCIÓN PALATINA EN EL CONCORDATO DE 1851}

El 17 de octubre de 1851, el Nuncio Giovanni Brunelli y el Ministro de Estado, Manuel Bertrán de Lis firmaron, en representación de Pío IX y la Reina

38 Cfr. A. Ponz, Viage de España, vol.V, ed. Vda. de Ibarra, Madrid, 1787, pp. 146-147.

39 Cfr. AGP RC C. ${ }^{\text {a }}$ 23/5 La carta lleva fecha del 9 de agosto de 1800.

40 Cfr. AGP RC C. ${ }^{\text {a } 23 / 5}$ Carlos IV posiblemente no intentó seguir adelante con su proyecto en primer lugar, porque San Francisco el Grande estaba ubicado fuera del territorio palatino y quizá también por sus diferencias, también políticas, con su primo Luis María de Borbón, Arzobispo de Toledo (1800$1823)$.

41 Cfr. ATLAS, p. 136. Se dividió Madrid en 14 Parroquias, además de la Real Parroquia de Palacio.

42 Cfr. R. García Villoslada (dir.), Historia de la Iglesia en España, BAC, Madrid, se citará HIE, vol. IV, p. 202.

${ }^{43} \mathrm{Al}$ remodelar la Puerta del Sol en 1854, las Cortes Constituyentes plantearon la edificación de edificios para la Bolsa, Junta de Comercio, Tribunales y una Catedral; Narváez pasó el proyecto a Obras Públicas que lo desestimó prevaleciendo el carácter popular y comercial de la zona. En 1869, tras el derribo de la antigua Parroquia de Santa María la Real de la Almudena, situada en la confluencia de las calles Mayor y Bailén, Ramón de Mesonero Romanos realizó propuestas para construir una Catedral digna de Madrid. El proyecto tomó cuerpo al crearse la Diócesis de Madrid-Alcalá en 1885 y la promesa de Alfonso XII de construirla para enterrar a su esposa María de las Mercedes. Vid. A. FERNÁNDEZ García (dir.), Historia de Madrid, Ed. Complutense, Madrid, 1993, pp. 419-434. 
Isabel II, un nuevo Concordato ${ }^{44}$. Se cita en él al Patriarca de las Indias y sus jurisdicciones exentas como Pro-Capellán de Palacio y Vicario Castrense, fijando su sueldo ${ }^{45}$.

El Concordato fue necesario no sólo para normalizar las relaciones bilaterales y actualizar los nombramientos episcopales (en 1847 había 40 vacantes), sino para reorganizar la obsoleta división eclesiástica de España, que la dinastía borbónica había mantenido prácticamente inalterada ${ }^{46}$. Multitud de privilegios, exenciones y peculiaridades de origen medieval dificultaban la administración diocesana ${ }^{47}$. No obstante, el Concordato mantuvo algunas jurisdicciones exentas, entre ellas, la del Pro-Capellán de Palacio y la del Vicario General Castrense, según consta en su artículo 11: «cesarán también todas las jurisdicciones privilegiadas y exentas, cualesquiera sea su clase y denominación (...) sus actuales territorios se reunirán a las respectivas diócesis en la nueva demarcación que se hará de ellas, salvas las exenciones siguientes:

1. ${ }^{\circ} \quad$ La del Pro-Capellán de Su Majestad.

2. ${ }^{\circ}$ La Castrense.

3. ${ }^{\circ}$ La de las cuatro Órdenes militares en los términos fijados en el artículo 9. ${ }^{\circ}$

4. ${ }^{\circ} \quad$ La de los prelados regulares.

5. ${ }^{\circ}$ La del Nuncio Apostólico pro tempore en la Iglesia y Hospital de los Italianos de esta Corte» ${ }^{48}$.

El artículo 21 del Concordato se refiere a la Real Capilla y, por tanto, a la jurisdicción palatina. Indica las iglesias de fundación real y Colegiatas que se conservarán tras el Acuerdo: «además de la Capilla Real de Palacio, se conservarán: $1 .^{\circ}$ la de los Reyes y la mozárabe de Toledo, las de San Fernando de Sevilla y la de los Reyes Católicos de Granada. 2. ${ }^{\circ}$ Las Colegiatas sitas en capitales de provincia donde no exista Silla episcopal(...)» ${ }^{49}$.

Otro artículo, el 19, trata también a la Real Capilla y, más concretamente, a

44 Vid. G. Martina, Pío IX: Chiesa e mondo moderno, Studium, Roma, 1976 y V. CÁrcel Ortí, «Pío IX e Isabel II, Nuevas cartas entre el Papa y la reina de España», Archivium Historiae Pontificiae, 21 (1983), pp. 131-181.

45 Cfr. J. Postíus, o. c., pp. 277-281.

46 Cfr. HIE, p. 191. Vid. V. CÁRCEL ORTí, «El nuncio Brunelli y el Concordato de 1851», Anales Valentinos, 1 (1975), pp. 79-198 y 309-377.

47 En España, antes del Concordato de 1851 había 252 Colegiatas y Capillas exentas Cfr. J. PÉREZ Alhama, La Iglesia y el Estado español. Estudio histórico jurídico a través del Concordato de 1851, Instituto de Estudios políticos, Madrid, 1967, p. 547.

48 Cfr. Postíus, o. c., p. 277.

49 Cfr. Postíus, o. c., p. 593. 
los cargos prebendados de la misma ${ }^{50}$. Se indica que «ni la Santa Sede ni la Reina conferirán ninguna dignidad, canonjía o beneficio de los que exigen personal residencia a los que por razón de cualquier otro cargo o comisión estén obligados a residir en otra parte (...) a no ser que renuncien a uno de dichos cargos o beneficios, los cuales se declaran, por consecuencia, de todo punto incompatibles.

En la Real Capilla, sin embargo, podrá haber hasta seis prebendados de las Iglesias Catedrales de la Península; pero en ningún caso podrán ser nombrados los que ocupan las primeras Sillas, los canónigos de oficio, los que tienen cura de almas, ni dos de una misma iglesia» ${ }^{51}$.

Es evidente que el clero de la Real Capilla siguió siendo privilegiado tras el Concordato de 1851, de acuerdo con una secular tradición, que no consiguió alterar el recorte de las prerrogativas eclesiásticas por parte del Gobierno durante varias décadas. No obstante, el número de seis prebendados supuso una limitación respecto a lo concedido por Gregorio XVI a la Reina Gobernadora en $1833^{52}$.

El artículo 31 del Concordato también alude al Patriarca de las Indias Occidentales, ya que fijaba, como en el caso de otros prelados, su sueldo anual. En el texto se lee: «la dotación del Patriarca de las Indias, no siendo Arzobispo u Obispo propio, será de 150.000 reales anuales, deduciéndose en su caso de esa cantidad cualquiera otra que por vía de pensión eclesiástica o en otro concepto recibiere del Estado». Se equiparaban sus emolumentos a los previstos para los prelados de las Archidiócesis de Sevilla y Valencia, inmediatamente por debajo del Arzobispo de Toledo (que debía percibir 160.000 reales anuales $)^{53}$.

Esta situación se mantuvo estable hasta 1885, año en que se creó la diócesis de Madrid-Alcalá y el Papa León XIII, a petición de Alfonso XII, suprimió el

50 Entre 1753 y 1815, los Capellanes de honor prebendados fueron 6; desde 1815 por Breve de Pío VII a Fernando VII se dobló el número de prebendados. Vid. BBP, pp. 479-481.

51 Según la Historia contemporánea del clero español, Editor José Llorente, Madrid, 1954 pp. 1-2 los prebendados de la Real Capilla para ese año fueron Marcos Aniano González (juez de la Real Capi1la), José Acisclo Valle, Alejo López Fraile, Ramón Durán de Corps (Rector de Santa Isabel), Fernando Balsalobre, Antonio Aguado López.

${ }^{52} \mathrm{El}$ texto de este Breve puede consultarse en $B B P$, pp. 485-493.

El número de Capellanes de honor durante el siglo XVIII y hasta el final del Reinado de Fernando VII fue de 40. Gregorio XVI concedió en 1833 que todos los Capellanes de honor de la Real Capilla conservaran sus prebendas; tras la pérdida de las provincias de ultramar, el Reglamento de la Real Capilla de 30-4-1838 redujo las plazas a 16 (12 del banco de Castilla y 4 de Órdenes militares). Según las Constituciones de la Real Capilla de 1849, los Capellanes de honor eran 18, 5 de ellos dotados por las Órdenes militares; de los 13 restantes, sólo 6 podían conservar la prebenda de la Diócesis de origen, de acuerdo con el Concordato de 1851. Sin embargo, en la práctica el número fue muy variable.

53 Cfr. J. Postíus, o. c., p. 281. 
cargo de Pro-Capellán ${ }^{54}$; los Arzobispos de Toledo y Santiago (con preeminencia histórica secular) compartieron por un periodo de siete años, la jurisdicción palatina habitual de modo conjunto y, a petición del Rey, podía ejercer la jurisdicción actual cualquiera de los dos Arzobispos, según la voluntad regia. El de Santiago mantuvo su jurisdicción privativa tradicional sobre el Monasterio de la Encarnación de Madrid y el título Patriarcal pasó al Arzobispo de Toledo que asumió el Vicariato Castrense ${ }^{55}$.

En 1892, al terminar el septenio, la Regente María Cristina de HabsburgoLorena (1885-1902) solicitó del Papa León XIII, a través del Cardenal Rampolla, que confirmara a los Arzobispos de Santiago y Toledo como capellanes mayores reales, pero con la posibilidad de delegar en la jurisdicción palatina y castrense en vicarios suyos que pudieran ser elevados al episcopado; se contemplaba la idea de que el Arzobispo de Toledo delegara sus funciones en un ProVicario, con el título episcopal de Sión, y que el Arzobispo de Santiago hiciera lo propio en un Pro-Capellán Mayor ${ }^{56}$. Fue Pro-Vicario y Pro-Capellán entre 1892 y 1923 Jaime Cardona y Tur, que en 1920 recuperó como Pro-Capellán Mayor, por la Bula Per similes (9-12-1920) de Benedicto XV (1914-1922), el título de Patriarca de las Indias que, temporalmente, había sido otorgado por León XIII al Arzobispo de Toledo ${ }^{57}$. Desde entonces, Cardona dejó de utilizar el título episcopal de Sión, por poseer la dignidad patriarcal ${ }^{58}$.

54 La nueva diócesis se creó por la Bula de León XIII Romani Pontífices Praedecessores ejecutada por el Nuncio Rampolla en la Catedral-Colegiata de San Isidro el 7 de marzo de 1885. Madrid-Alcalá fue elevada al rango de Archidiócesis por Pablo VI por la Bula Romani Pontificum semper fechada el 25 de marzo de 1964. En el Archivo Vaticano se encuentra la documentación relativa al inicio de la Diócesis. Vid. F. DíEz DE CERIO, Índice-Catálogo de Fondo de la Nunciatura en Madrid en el Archivo Vaticano 1794-1879, tomo III, Universidad Gregoriana, Roma, 1993: Caja 5403830 n. 6 erección Diócesis, $\mathrm{n}^{\circ} 7$ Nuovo ordinamento delle gurisdizioni palatine e castrense.

Sobre la supresión del Pro-Capellán, Cfr. LEÓN XIII, «Carta Apostólica Paterno semper affectu (21-4-1885)», en Acta Leonis Pontificis Maximi, vol. V, pp. 39-41, Roma, 1885; el texto es comentado por J. Postíus, o. c., p. 536.

55 Cfr. J. Postíus, o. c., pp. 536-537. El primer Arzobispo de Toledo, que fue nombrado Capellán Mayor, Vicario General Castrense y Patriarca de las Indias fue entre 1885 y 1886 fue Ceferino González. AGP PER 2632/27.

56 Sión es una sede episcopal de Asia Menor que dejó de tener Obispos residenciales en el año 787, con la invasión musulmana. Cfr. P. GAMs, Series Episcoporum Ecclesiae latinae, ed. K. W. Hiersemann, Leipzig, 1931 p. 444.

57 Cfr. Acta Apostolicae Sedis (AAS), 12 (1920), p. 594. Se ha consultado en la Biblioteca de la Conferencia Episcopal Española (BCEE).

${ }^{58}$ Cfr. J. Postíus, o. c., pp. 592, y J. Ferreres, o. c., p. 251. Le sucedieron en ambos cargos Julián de Diego y García Alcolea (1923-25) Francisco Muñoz Izquierdo (1925-30) y Ramón Pérez Rodríguez (1930-1931).

Hispania Sacra, Legalidad y conflictos, 58

117, enero-junio 2006, 145-170, ISSN: 0018-215-X 


\section{FIN DE LA JURISDICCIÓN PALATINA}

Durante la II República quedaron abolidas las jurisdicciones palatina y castrense $^{59}$. Según María Victoria Quero, autora del artículo correspondiente a la voz Capilla Real del Diccionario de Historia Eclesiástica de España, «la jurisdicción eclesiástico-palatina perduró como tal jurisdicción exenta hasta la caída de la Monarquía el 14 de abril de $1931 »^{60}$.

¿Fue realmente suprimida la jurisdicción palatina el 14 de abril de 1931 ? En las siguientes líneas, nos proponemos demostrar que no, puesto que pervivió exactamente hasta dos años más tarde, el $1 .^{\circ}$ de abril de 1933, fecha del nombramiento de Ramón Pérez Rodríguez, Patriarca de las Indias como Obispo de Cádiz-Ceuta por la Sagrada Congregación Consistorial ${ }^{61}$.

En los días inmediatos a la proclamación de la II República, se promulgaron las medidas legales necesarias sobre los bienes que fueron de la Corona, incluidos los Patronatos reales. Sobre el personal que trabajaba en dichas propiedades se publicaron los decretos correspondientes en los siguientes meses ${ }^{62}$.

De junio de 1931 cabe reseñar algunos hechos relacionados con la Real Capilla. El 1 de junio el Patriarca de las Indias, Pérez Rodríguez administró en la Parroquia del Buen Suceso (Ministerial de Palacio) el sacramento de la Confirmación a un grupo de niños y adolescentes. Esta ceremonia se repitió en oca-

59 La palatina se suprimió teóricamente el 14 de abril de 1931 Cfr. AGP Expediente personal de Ramón Pérez Rodríguez PER 4430/25. La castrense estuvo vigente hasta el 1 de abril 1933 Cfr. Boletín Oficial del Obispado de Madrid-Alcalá, 1-4-1933 n. ${ }^{\circ}$ 1580, pp. 113-114., y L. AlONSO MuÑoyerro, La Jurisdicción eclesiástica castrense en España, Ed. Castrense, Madrid, 1954, p. 12.

${ }^{60}$ Cfr. DHEE, «Capilla Real». La autora, María Victoria Quero, conoció este testimonio por su tío Pedro Álvarez Soler, Canónigo de la S.I.C. de Madrid y Defensor del Vínculo de la Rota Española, estudioso de la jurisdicción palatina, ya fallecido, amigo de Buenaventura Gutiérrez Sanjuan, último Rector del Patronato de Santa Isabel (1919-1931) bajo la Monarquía. Álvarez Soler recordaba que Gutiérrez Sanjuán, a su pregunta sobre el fin de dicha jurisdicción durante una conversación mantenida en los años 50, le contestó taxativamente que había terminado el 14 de abril de 1931. Por instrucciones dadas desde la Nunciatura al Patriarca de las Indias, de acuerdo con la Santa Sede, se traspasó dicha jurisdicción al entonces Obispo de Madrid-Alcalá, Mons. Eijo y Garay, de quienes pasaron a depender las personas vinculadas a la misma, según supo el propio Rector de Santa Isabel mediante llamada telefónica a la Nunciatura, ya que el Patriarca de las Indias se hallaba ausente.

No se conserva en la Nunciatura de Madrid documentación anterior a 1939, por tanto, habría que acudir a Roma para localizar entre los documentos relativos al Nuncio Tedeschini una confirmación escrita de dicho testimonio. No obstante, como veremos, en la práctica, la jurisdicción palatina no terminó hasta abril de 1933, será innecesario, por tanto, intentar la búsqueda de un documento vaticano anterior, que confirme el testimonio de Gutiérrez Sanjuán, quien efectivamente se desligó de la jurisdicción palatina en 1931.

61 Anuario Eclesiástico 1934, Ed. Subirana, Barcelona, 1934 p. 73.

62 Se mantuvo al personal jornalero-obrero por Decreto del 30-4-1931 Gaceta de Madrid, GM (24-4-1931), n. ${ }^{\circ}$ 124; al personal subalterno de plantilla de la Casa Real se les pasó a considerar empleados públicos cesantes Decreto 22-7-1931, GM (23-7-1931), n. 760. 
siones posteriores, concretamente tres veces más a lo largo del año 1932 (23 de junio, 10 y 23 de diciembre); sabemos por los respectivos asientos de los Libros Parroquiales que desde el 1 de junio de 1931 no volvió a utilizar el título de Pro-Capellán ${ }^{63}$.

Sin embargo, pocos días más tarde, el 16 de junio, la Dirección General de Propiedades y Contribución Territorial del Ministerio de Hacienda eliminaba del servicio activo al personal de la Real Capilla. Es decir, que el Ministerio de Hacienda dejó de pagar a los empleados de la Real Capilla desde junio de 1931. En el expediente personal de Ramón Pérez Rodríguez, último Patriarca de la jurisdicción palatina, se encuentra la siguiente anotación: El Excmo. Sr. Ministro de Hacienda a propuesta de la Dirección General de Propiedades y Contribución territorial se ha servido disponer con fecha 16 de junio de 1931 lo siguiente: «Eliminar de las plantillas del servicio activo a todo el personal que estaba afecto a la Capilla del que fue Palacio Real» ${ }^{64}$.

Desde junio de 1931, cesaron en sus empleos los clérigos de los Patronatos que pertenecieron a la Corona. Meses más tarde, se procedió a dar normas sobre estas vacantes en los antiguos Patronatos: serían provistas por el Presidente de la República, como Patrono titular, a propuesta del Ministerio de Gobernación del que dependían como instituciones benéficas que debían seguir cumpliendo sus funciones ${ }^{65}$.

También dos años después de la caída de la Monarquía, concretamente el 1 de abril de 1933, tuvo lugar un hecho decisivo relacionado con el citado Patriarca de las Indias Occidentales: el fin de la jurisdicción castrense. El Nuncio Apostólico en España, Mons. Tedeschini, declaraba extinguido el Breve de 1-41926, otorgado por Pío XI (última renovación del acuerdo sobre la jurisdicción castrense, que debía actualizarse cada siete años $)^{66}$. Se traspasó, desde abril de

\footnotetext{
${ }^{63}$ En las Confirmaciones de 1932 utiliza el título Patriarcal. Vid. AGP Libros Parroquiales n. 37 La administración de este sacramento después del 14-4-1931 en la Parroquia del Buen Suceso (Ministerial de Palacio), indica que el Patriarca siguió ejerciendo de modo efectivo su jurisdicción. Durante la I República, concretamente entre el 28 de febrero de 1872 y el 11 de febrero de 1875 no se administró este sacramento en la Parroquia Ministerial de Palacio, con sede en la iglesia de la Encarnación, según indica el Libro Parroquial n. ${ }^{\circ} 36$.

64 Vid. AGP PER 4430/35 y Documentación Anexo 44 p. 478. También en el expediente de Juan Causapié AGP PER 178/73. Llama la atención que esta cláusula conste en expedientes personales de antiguos miembros de la Real Capilla, incluso en los ya difuntos, como el Patriarca Julián de Diego y García Alcolea, fallecido en 1925. Vid. AGP PER 1149/39.

65 Cfr. «Decreto 20-11-1931», en GM (26-11-1931), n. ${ }^{\circ}$ 1534. Los clérigos que ocuparon cargos en la Real Capilla con sede en el Patronato del Suceso: Patriarca de las Indias: Ramón Pérez Rodríguez; Fiscal de la Real Capilla y Vicario General del Buen Suceso: Gabriel Palmer; Secretaría de la Jurisdicción palatina: Pedro Poveda Castroverde y Emilio Rodríguez Muñoz; Archivo y Secretaría del Patriarca: José María López de Diego.

66 Otro hecho significativo de esta etapa fue el cierre del Tribunal de la Rota en la Nunciatura el 21 de junio de 1932 y su disolución por Pío XI el 1 de agosto de 1933 en protesta a la legislación en mate-
} 
1933, la jurisdicción sobre los antiguos Patronatos reales y las personas vinculadas a la jurisdicción palatina al Obispo de Madrid-Alcalá, Mons. Eijo y Garay ${ }^{67}$. El título de Patriarca de las Indias, tras la Guerra Civil, volvió a ser usado desde el 11 de octubre de 1946 por el citado Obispo de Madrid, último en ostentarlo, con un carácter personal y meramente honorífico, hasta su muerte en 1963 (después el título no ha sido suprimido formalmente) ${ }^{68}$.

\section{UNA PRELATURA VERE NULLIUS DE HECHO}

Después de pasar revista a las circunstancias históricas que atravesó la jurisdicción palatina interesa reflexionar sobre la naturaleza de la misma.

Antes de ser elegido Papa con el nombre de Benedicto XIV, Próspero Lambertini, uno de los mejores canonistas de su época, dividía a los prelados inferiores en:

a) Prelados de clase $1 .^{\mathrm{a}}$ con jurisdicción ínfima: son los prelados regulares o superiores religiosos exentos de la jurisdicción episcopal dentro de la clausura.

b) Prelados de clase $2 .^{\mathrm{a}}$ con jurisdicción media o prelados quasi nullius: son prelados con jurisdicción exenta sobre clero y pueblos pero sin territorio.

c) Prelados de clase $3 .^{a}$ con jurisdicción superior o prelados vere nullius: son prelados con jurisdicción exenta sobre clero y pueblo con territorio separado llamado abadía o prelatura vere nullius ${ }^{69}$.

Desde el siglo XIII en que se concedió la exención jurisdiccional hasta 1753, la Real Capilla fue una suerte de prelatura quasi nullius, con clero y pueblo pero sin territorio, de acuerdo con los criterios de Benedicto XIV, recogidos posteriormente por el Código de Derecho Canónico de 1917. A partir de 1753, puede considerarse, de hecho, una prelatura vere nullius, con clero, pueblo y territorio.

\footnotetext{
ria matrimonial de la II República. Cfr. M. CALvo Tojo, «Aportación del Tribunal de la Rota de la Nunciatura a la Iglesia Española», La Administración de la justicia eclesiástica en España, 236 (2001), p. 122.

67 Cfr. L. Alonso MuÑoyerro, o.c., pp. 11-12, y DHEE, «Vicariato Castrense». El último Breve renovado fue el de Pío XI el 1-4-1926. Expiró en 1933 y no se renovó, porque la II República había disuelto el Cuerpo Eclesiástico Castrense. p. 2743.

68 Vid ABADÍA, pp. 310-324.

69 Vid. Benedicto XIV, De sínodo dioecesana, Ferrariae, 1760 y Código de Derecho Canónico (1917) CIC, cc. 319-328.
} 
Partiendo de la división realizada por Benedicto XIV, la jurisdicción palatina ha sido estudiados desde distintos puntos de vista por diversos autores: entre otros, canonistas de los años veinte del pasado siglo que han comentado el Código de 1917 (Ferreres y Postíus); canonistas contemporáneos que han tratado sobre la naturaleza de la jurisdicción de los prelados inferiores y de las diversas circunscripciones eclesiásticas (Miras y Viana); historiadores de los siglos XIX y XX que han abordado el tema con un enfoque de carácter institucional (de la Fuente, Fernández Duro, Frías, los autores del Diccionario de Historia Esclesiástica de España, Bazán Ocón, Linage Conde); cada uno desde su perspectiva ha aportado datos de gran interés.

Teniendo en cuenta la realidad histórica de la jurisdicción palatina, el estudio ya clásico de Ferreres resulta acertado al definir el carácter mixto (territorial con fundamento personal) de la Real Capilla, ya que en su origen, la jurisdicción palatina tuvo carácter personal (la atención pastoral de la Familia real, los cortesanos y los servidores de Palacio) hasta su completa territorialización entre 1753 y 1777 , aunque mantuvo su fundamento originariamente personal.

La jurisdicción palatina, regida por un derecho privilegiado, puede considerarse semejante a una prelatura territorial vere nullius desde entonces, pero de carácter especial, que nunca fue oficialmente reconocida por la Santa Sede.

Fue singular porque asumió aspectos propios de una prelatura territorial exenta, características de una Catedral o Colegiata y rasgos externos de un arciprestazgo, aunque desde el punto de vista canónico realmente sólo fuera una Parroquia muy peculiar:

- Fue erigida como Parroquia en 1753 y se proyectó sin éxito elevarla a rango catedralicio antes de la Guerra de la Independencia. Fue definitivamente territorial desde 1777, pero su fundamento era personal (atención pastoral a la Corte y servidores de Palacio). Es indudable que hasta 1777 la jurisdicción palatina tuvo características muy semejantes a una jurisdicción quasi nullius como el Vicariato Castrense y fue, por tanto, muy semejante a una prelatura de carácter personal, de hecho, en los documentos coetáneos hay referencias a la parroquialidad personal de la Real Capilla ${ }^{70}$.

- Su territorialidad fue fijada para evitar conflictos con otras jurisdicciones eclesiásticas y debido a que éstas han estado habitualmente ligadas a un territorio delimitado; pero en sí misma considerada, la jurisdicción palatina poseía un carácter personal.

70 En un Informe de 1756, el Cardenal Patriarca Mendoza utiliza en cinco ocasiones los términos parroquialidad personal. Cfr. BBP, pp. 620-658.

Hispania Sacra, Legalidad y conflictos, 58

117, enero-junio 2006, 145-170, ISSN: 0018-215-X 
- La Real Parroquia de Palacio poseyó un Cabildo semejante al de una Catedral o Colegiata: hasta final del reinado de Fernando VII estaba integrado por 40 Capellanes de honor; con la Reina Gobernadora se redujeron a $16 \mathrm{y}$, desde 1849 fueron 18. Por privilegio papal, parte de los Capellanes de honor poseían prebendas catedralicias en otras ciudades sin obligación de residir en ellas, incluso después del Concordato de 1851, que lo prohibía expresamente. El Cabildo palatino mantuvo, en mayor o menor grado, sus exenciones y privilegios y los defendió tenazmente, acudiendo cuando fue necesario a la Santa Sede.

- Desde sus orígenes la Real Parroquia de Palacio tuvo penitenciario, como las Colegiatas o Catedrales.

¿Fue realmente exenta, privativa y episcopal la jurisdicción del Pro-Capellán con un oficio equiparable al de los obispos diocesanos? ${ }^{71}$.

Los Breves de 1753 y 1777 y el resto de la documentación consultada no dejan lugar para la duda: el Pro-Capellán, Patriarca de las Indias Occidentales, como cabeza habitual de la jurisdicción palatina era: ordinario, rector, juez, administrador del territorio separado vere nullius, poseía omnímoda jurisdicción privativa episcopal vel quasi y sus feligreses están exentos de los Obispos ordinarios.

Conviene recordar, en primer lugar que el caso del Pro-Capellán fue sumamente particular porque ejerció una jurisdicción episcopal pero de modo vicario, puesto que el Capellán titular siempre fue el Arzobispo de Santiago de Compostela o, conjuntamente éste y el de Toledo entre 1885 y 1892.

Además, aunque los documentos repitan constantemente que la del Pro-Capellán fue una jurisdicción exenta y privativa, por el hecho de estar financiada por la Corona y para evitar conflictos con Toledo, la Real Capilla y otras iglesias de la jurisdicción palatina renunciaron a los diezmos (hasta su supresión en 1837) y a las limosnas de los funerales (que suponían la mayor parte de los ingresos de cualquier Parroquia). Desde esa perspectiva, el Pro-Capellán, por tanto, cedió algunos de sus derechos a favor de la archidiócesis de Toledo ${ }^{72}$.

Cabe plantearse hasta qué punto fue realmente semejante la jurisdicción palatina del Pro-Capellán de Palacio a la episcopal. Un estudioso de la jurisdicción palatina, Ferreres, al tratar sobre su naturaleza, afirma que «es no sólo parroquial, sino además episcopal» ${ }^{73}$.

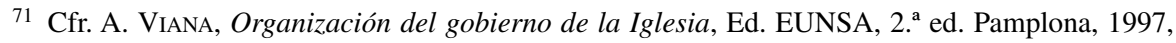
pp. 139-140.

72 Por su parte, Toledo tuvo que ceder para la manutención del Pro-Capellán su arcedianato hasta que el Concordato de 1851 fijó un sueldo para el Patriarca.

73 J. N. FERRERES, o.c., p. 251. 
Múltiples argumentos apoyan el carácter episcopal o quasi episcopal de la cabeza de la jurisdicción palatina:

a) Todos los Pro-Capellanes de Palacio, desde el Breve de parroquialidad de 1753, fueron al menos Obispos titulares o habían sido previamente Obispos residenciales. Los Pro-Capellanes interinos, que ocuparon el cargo en circunstancias difíciles para la Real Capilla, fueron generalmente presbíteros con una jurisdicción asimilada a la episcopal, salvo algunos que eran ya Obispos antes de ocupar el cargo ${ }^{74}$.

b) De acuerdo con su rango, algunos Pro-Capellanes gozaron, por privilegio papal hasta la etapa de María Cristina de Borbón como Reina Gobernadora, del arcedianato de Toledo, una de las prebendas eclesiásticas más cotizadas ${ }^{75}$; posteriormente, en el Concordato de 1851 se les asignó, a los que no fueran Obispos residenciales, un sueldo equiparable al de los Arzobispos de Sevilla y Valencia ${ }^{76}$.

c) En la vida real, el Pro-Capellán actuó como Obispo de Palacio, se ocupaba de tareas claramente episcopales:

- Comunicación de las publicaciones de la Santa Sede a sus feligreses.

- Promoción de la unidad con la Sede Romana (oraciones, colectas, celebración de aniversarios).

- Ordenamiento de las actividades pastorales en su demarcación (cumplimiento del precepto pascual, indulgencias, planificación de sermones, calendarios litúrgicos, renovación de santos óleos).

- Selección y presentación de clérigos candidatos a atender a sus feligreses.

- Colación canónica de cargos y licencias ministeriales.

- Administración de los sacramentos a la Familia real.

\footnotetext{
${ }^{74}$ Los Pro-Capellanes interinos presbíteros fueron: Pedro de Silva, bibliotecario de Carlos IV (1808-1810), Miguel Oliván López, juez de la Real Capilla (1810), Joseph Duaso (1810 y 1834), Pedro Antonio Mejías (1839), Juan López Pelegrín (1839), Faustino Losada Cruz (1849), Nicolás Luis Lezo de Garro (1850-51), Vicente Valls (1869), José Pulido Espinosa (1870-1872), Hilario Blanco (1885), Los Pro-Capellanes interinos Obispos fueron Pedro Chaves de la Rosa (1813-14) Obispo de Arequipa, Miguel Frayle García (1834-1836), Obispo de Sigüenza, Pedro José de Fonte (1837-1839), Arzobispo de México.

75 Esta prebenda privilegiada fue defendida en varias ocasiones frente a la Sede Primada por diversos Papas en 1815,1820 y 1833 . Vid. BBP, pp. 482-487.

${ }^{76}$ El sueldo era de 150.000 reales anuales, sólo superado por el Arzobispo de Toledo. Cfr. J. PosTíus, o.c., Concordato de 1851 artículo 31. 
- Nombramiento párrocos, confesores y penitenciarios.

- Supervisión de la vida parroquial.

- Administración del sacramento de la Confirmación a sus feligreses.

- Celebración de capillas públicas en el Real Capilla en las solemnidades litúrgicas.

- Nombramiento de Capellanes de honor (su Cabildo) y personal eclesiástico de los Patronatos reales.

Parece que efectivamente el Pro-Capellán y Patriarca de las Indias Occidentales, ejerció una auténtica y tangible jurisdicción episcopal asumiendo, según Postíus, «todas las facultades que por derecho, de hecho, o por costumbre gozan los demás Obispos» ${ }^{77}$.

De acuerdo con las Constituciones y Reglamentos de la Real Capilla, el ProCapellán: «dará poder y comisión según y como lo dan los Arzobispos y Obispos en sus diócesis, para que conozca de todas las causas de los Capellanes de honor, cantores, músicos y demás ministros así eclesiásticos como seculares de la Real Capilla. Asimismo de todos lo feligreses y parroquianos de la Parroquia de Palacio» ${ }^{78}$.

Del Pro-Capellán dependía el juez de la Real Capilla, encargado directamente de garantizar la defensa de la jurisdicción y la aplicación de las leyes eclesiásticas generales y el derecho privilegiado de la Real Capilla. Según éste último, de acuerdo con las Bulas y Breves pontificios para la Real Capilla, el Pro-Capellán estaba facultado para:

a) «Oír, examinar y terminar todas las causa civiles, criminales, mixtas de sus súbditos sumariamente y de plano, excepto las causas beneficiales de los súbditos beneficiados de otras iglesias.

b) Promover a sus súbditos a las sagradas órdenes con testimoniales de sus ordinarios y a extraños con dimisorias de sus prelados, pudiendo despachar dimisorias a sus ordenandos súbditos.

c) Resolver causas matrimoniales, además de solemnizar cualquier matrimonio de sus súbditos» ${ }^{79}$.

Por lo que respecta a estas causas señaladas, propias de la jurisdicción del Pro-Capellán, existe documentación sobre:

77 J. Postíus, o.c., p. 537.

78 Cfr. AGP RC L. 1133 Reglamento de la Real Capilla (22-6-1802) art. 4. ${ }^{\circ}$

79 J. Postíus, o.c., pp. 537-538. 
a) Causas judiciales varias:

- Causas civiles y criminales de miembros de la Real Capilla (son frecuentes el impago de alquileres de músicos de la Real Capilla, secuestros, robos y desaparición de documentos, etc.)

- Causas relativas a la defensa de la jurisdicción palatina, especialmente frente a la de Toledo, con la que tuvo mayor número de conflictos.

b) Causas beneficiales:

Los Capellanes de honor (Cabildo del Pro-Capellán), según se ha indicado, gozaron de prebendas eclesiásticas de diversas Catedrales de España y América; desde el Papa Sixto IV (1474) el Capellán Mayor o su teniente podía oír, conocer y sentenciar definitivamente controversias pleitos y disputas beneficiales y seculares entre capellanes, cantores y demás miembros de la Real Capilla, pero los posibles pleitos contra terceros, dependían del Obispo de la diócesis de origen de la prebenda. No obstante, la Santa Sede intervino en varias ocasiones a principios del siglo XIX para asegurar la conservación de prebendas para la Real Capilla, especialmente tras la pérdida de las provincias de Ultramar.

c) Atribuciones sobre los sacramentos del orden y el matrimonio:

Con relación al sacramento del Orden, como se ha indicado, esa atribución episcopal fue escasamente ejercida por los Pro-Capellanes, puesto que muchos clérigos de provincias deseaban encontrar una colocación en la Villa y Corte. Las ordenaciones en la jurisdicción palatina fueron, por tanto, infrecuentes ${ }^{80}$. Una posible explicación es la siguiente: como en el caso de la jurisdicción castrense (en esto se asemejan), el presbiterio de la jurisdicción palatina estaba integrado por clérigos de otras diócesis que, temporal o definitivamente, ejercían su ministerio entre los fieles de Palacio.

En cuanto al sacramento del matrimonio, los expedientes matrimoniales de las personas de la jurisdicción palatina, de acuerdo con la documentación consultada, se abrían en la Parroquia Ministerial. El juez de la Real Capilla otorgaba permiso para incoar un expediente matrimonial entre los súbditos del Patriarca y los responsables materiales de ejecutarlos y custodiarlos eran los párrocos de la jurisdicción ${ }^{81}$. Por lo que respecta a otras atribuciones del ProCapellán con relación a los matrimonios de sus feligreses, cabe señalar dos épocas bien definidas:

\footnotetext{
${ }^{80}$ Desde el siglo XVIII, sólo consta que administraran el sacramento del orden los Patriarcas Borja y Centelles, Mendoza, Sentmenat e Iglesias y Barcones.

81 AGP Libros Parroquiales, n. ${ }^{\circ}$ 45, fol 4 (Matrimonios 1756-1785).

Hispania Sacra, Legalidad y conflictos, 58

117, enero-junio 2006, 145-170, ISSN: 0018-215-X
} 
- Desde el Concilio de Trento hasta la Guerra de la Independencia, el Patriarca actuó como cualquier otro Ordinario en su demarcación, es decir, como juez de primera instancia, por concesión vaticana. Consta que en 1745, (antes incluso que el Breve de parroquialidad palatina) el Nuncio remitió al Patriarca de las Indias Occidentales, una Constitución Apostólica sobre algunas causas de nulidad matrimonial, para que las hiciera observar en su jurisdicción, si se diera el caso ${ }^{82}$.

- A partir de los inicios del siglo XIX la praxis se modificó, debido a la creación del Tribunal de la Rota en la Nunciatura de España en 1771 por el Papa Clemente XIV. Según el Breve de 26-12-1771 Administrandae iustitiae zelus, pasaban a la jurisdicción de la Rota «en primera instancia las causas de los Regulares y demás exentos, y en grado de apelación las falladas por los Arzobispos y Obispos españoles» ${ }^{83}$. Pocos años más tarde, por Real Decreto de 17-4-1779, se ordenaba al Patriarca de las Indias que cumpliera los autos y providencias de la Rota ${ }^{84}$. Se confirma, por tanto, que durante los siglos XIX e inicios del XX, los pleitos matrimoniales de la jurisdicción palatina, que era exenta, se llevaran a término directamente a través de la Rota Española. A. Linage afirma en este sentido que en materia de procesos canónicos, tanto la jurisdicción palatina como la castrense presentaban los pleitos ante el Tribunal Supremo de la Nunciatura ${ }^{85}$.

Después de exponer algunas características de la jurisdicción del Pro-Capellán de Palacio, interesa conocer algunos rasgos propios de la Real Parroquia palatina. Para calibrar si la Parroquia palatina era semejante a las diocesanas; se puede, en primer lugar, realizar una comparación cuantitativa centrada en el siglo XIX, época de la que se han realizado varios estudios.

Antes de la Guerra de la Independencia, en España, las Parroquias ocupaban una media de $25 \mathrm{~km}^{2}$, agrupando a unos 1000 habitantes de promedio ${ }^{86}$. Del Madrid de la misma etapa, existen estudios pormenorizados que señalan la diferencia entre extensión y número de fieles de Parroquias céntricas y periféricas. Ejemplo válido es el de las Parroquias de Santiago con 2,5 hectáreas de territorio y 997 almas, y la de San Martín, con 136,7 ha. y 35.498 feligreses ${ }^{87}$.

82 AGP RC C. ${ }^{a} 4 / 3$.

83 Vid. J. Morera SABATER, «Breve historia de la Rota Española» en Normae a Rota Nuntiaturae Apostolicae in Hispania servandea necnon et Ordo pro causis iudicialibus in eodem tribunali expediendis, Matriti, 1962, pp. 60-74.

${ }^{84}$ Cfr. Ibidem, p. 64.

85 Cfr. DHGE, p. 1045.

${ }^{86}$ Cfr. M. Teruel Gregorio de Tejada, o.c., p. 298.

87 Cfr. ATLAS, pp. 351-352. Los datos corresponden a la matrícula Parroquial, que incluye a quienes cumplieron el precepto pascual en 1792. En Madrid había un total de 154.114 almas de comunión y 12 Parroquias; la media era de 12.843 feligreses. 
Por lo que respecta estrictamente a la Parroquia de Palacio en esos años, concretamente en 1802, tenía 836 feligreses (sin contar los Reales Sitios y Patronatos reales de su jurisdicción); siguiendo ese mismo criterio territorial, su extensión era de $0,5 \mathrm{~km}$ cuadrado ${ }^{88}$.

A inicios del siglo XIX, la real Parroquia de Palacio era territorialmente la más pequeña de Madrid, pero su número de feligreses (836) era semejante al de una Parroquia menor de la Villa y Corte y cercana a la media nacional.

Ferreres afirma taxativamente que «el carácter territorial de la jurisdicción palatina se confirma por el hecho de ser erigida en Parroquia, con los mismos derechos y prerrogativas que otras Parroquias territoriales» ${ }^{89}$ A pesar de ello, según los documentos consultados, no parece posible mantener esta proposición: la Real Capilla no fue una Parroquia como las demás territoriales, por los siguientes motivos:

- En el territorio palatino había, como se ha indicado, hasta tres parroquias: la Ministerial de Palacio (desde 1885 con sede en el Patronato del Buen Suceso de la Calle de la Princesa), la parroquia de El Pardo y la de Aranjuez. Según el Código de Derecho Canónico de 1917 era suficiente para ser erigida en prelatura nullius, aunque de hecho, nunca tuvo ese rango, ni siquiera el de arciprestazgo ${ }^{90}$.

- La Real Parroquia de Palacio se diferenciaba en su régimen financiero de las diocesanas: estaba dotada por la Casa Real; sus feligreses no aportaban diezmos ni limosnas por los funerales, que entregaban a la más cercana a su domicilio.

- La Parroquia palatina ejerció el ius sepelendi, el derecho parroquial de enterrar a sus feligreses desde la erección de la Real Capilla como Parroquia en 1753. No obstante, sus parroquianos podían elegir el lugar de sepultura libremente. Hasta mitad de siglo XIX utilizaron para los entierros la Parroquia Ministerial de Palacio u otras de Madrid; después, el Cementerio Patriarcal o bien otros de la capital.

En definitiva, la Real Capilla de Palacio fue de hecho, desde mitad del siglo XVIII, semejante a una prelatura territorial exenta aunque nunca llegó a ser erigida como tal y pervivió como una peculiar parroquia cuyo prelado poseía rango episcopal.

\footnotetext{
${ }^{88}$ Cfr. AGP Registros 6171.

89 Cfr. J. B. FerReres, S.I., o.c., p. 251.

90 Cfr. Postíus, o.c., p. 535.
} 